\title{
KEHANCURAN PRODUKSI DAN HILANGNYA PABRIK KINA MASA \\ KOLONIAL DI BANDUNG: BUKTI BENCANA BUDAYA DAN SOSIAL
}

\section{Production Destruction And The Loss Of Colonial Cinchona Factory In Bandung: \\ The Cultural And Social Disaster}

\author{
Lia Nuralia \\ Balai Arkeologi Jawa Barat \\ Jalan Raya Cinunuk Km. 17 Cileunyi, Bandung 40623 \\ E-mail: liabalar@yahoo.com
}

\begin{abstract}
The Cinchona Plantation in Bandung, West Java, is almost extinct and the current production of Cinchona is only at the Bukit Unggul of Cinchona Factory. Why only one factory is still operating and why the loss of a factory building is importan, are the main issues in this paper. The method used is archaeological research method with a historical approach. The purpose of this paper is to find out the causes of the destruction of production and the loss of cinchona factory building during the colonial period as a cultural or social disaster. The traces of the former cinchina factory in order former cinchona plantations can still be traced in a incomplete and neglected physical condition. Loss of traces of plantation culture of historical value and a source of knowledge is important imformation to know.
\end{abstract}

Keywords: The destruction of cinchona production, the cinchona factory, the cultural disaster

\begin{abstract}
Abstrak
Perkebunan kina di Bandung Jawa Barat hampir punah dan produksi kina yang masih berlangsung sekarang hanya ada di Pabrik Kina Bukit Unggul. Mengapa hanya tinggal satu pabrik yang masih beroperasi, dan mengapa kehilangan bangunan pabrik menjadi penting, menjadi permasalahan pokok dalam tulisan ini. Metode yang digunakan adalah metode penelitian arkeologi dengan pendekatan sejarah. Tujuan tulisan ini adalah mengetahui penyebab kehancuran produksi dan hilangnya bangunan pabrik kina masa kolonial sebagai satu bencana budaya atau bencana sosial. Bekas pabrik kina di lokasi bekas kebun kina lainnya masih bisa ditelusuri jejaknya dalam kondisi fisik tidak utuh dan terabaikan. Kehilangan jejak budaya perkebunan bernilai sejarah dan sumber ilmu pengetahuan menjadi informasi penting diketahui.
\end{abstract}

Kata kunci: Kehancuran produksi kina, pabrik kina, bencana budaya.

\section{PENDAHULUAN}

Usaha perkebunan besar di Priangan tidak lepas dari sejarah imperialisme dan kolonialime Eropa di Asia, termasuk di Hindia Belanda. Kopi menjadi tanaman awal perkebunan yang legendaris, karena memberikan keuntungan kolonial sangat besar dari kerja paksa (Breman, 2014). Sistem Prengersetelsel di Priangan merupakan daerah wingewest atau daerah yang menguntungkan negara induk (Kurniawan, 2014). Kopi Priangan menjadi komoditas ekspor unggulan di dunia internasional.

Politik eksploitasi tanah jajahan kemudian dilakukan melalui Cultuurstelsel, dengan komoditas kina dan teh. Eksploitasi tanah jajahan melalui usaha perkebunan 
besar, dilakukan untuk mengatasi keuangan negeri induk Belanda yang sedang mengalami kemerosotan (Kartodirdjo \& Surjo, 1991) akibat perang dunia.

Sistem Preangerstelsel dan Cultuurstelsel berhasil membuat Pemerintah Hindia Belanda meraup keuntungan finansial tinggi. Harga rendah dan tenaga murah serta lahan kebun luas tidak bertuan adalah faktor utama dalam keberhasilan usaha perkebunan besar. Lahan "liar" (woeste gronden) ${ }^{1}$ merupakan lahan yang tersedia untuk disewa ketika itu (Kartodirdjo \& Surjo, 1991), melalui hak erfpacht dan eigendom (Simarmata, 2002).

Sistem Tanam Paksa berjalan selama 40-50 tahun (1831-1870) sebagai bentuk eksploitasi tanah jajahan yang paling strategis (Van Niel, 1988). Kemudian Sistem Tanam Paksa dihapus tahun 1870 setelah Novel "Max Havelaar" beredar sampai ke Belanda, mendapat reaksi keras dari Kaum Liberal (Hermans, 1988). Namun, praktek Tanam Paksa dalam kenyataannya tetap berlanjut. Sistem Pemerintahan Hindia Belanda yang tidak langsung (indirect rule) memudahkan praktek Tanam Paksa, melalui perpanjangan tangan elite pribumi. Tradisi "kepatuhan tradisional" rakyat pribumi kepada pemimpinnya (Sutherland, 1983), menjadikan praktek tersebut dapat bertahan untuk beberapa waktu lamanya (Nuralia, 2015).

Produksi kina di akhir abad ke-19 dan awal abad ke-20 di Priangan merajai komoditas ekspor di dunia internasional. Industri perkebunan kina masa kolonial pernah berjaya di dunia internasional. Pada tahun 1900-an terdapat 82 kebun kina di Jawa Barat, dan 60 kebun kina ada di wilayah Bandung. Selebihnya ada di daerah Garut, Bogor, dan lain sebagainya. (Regerings Almanak voor Nederlandsch-Indie (1892, 1893,1900, 1901, 1902, 1906) Eeerste Gedeelte, Grondgebied en Bevolking, Inrrichting Van Het Bestuur Van Nederlandsch-Indie En Bijlagen). Kondisi tersebut di masa sekarang dapat ditelusuri melalui jejak budaya perkebunan. Warisan budaya tersebut merupakan "kode budaya" kolonial (Nuralia, 2016), yang "bercerita" tentang produksi kina di masa lalu, melalui simbol-simbol budaya sebagai komunikasi nonverbal.

Penelitian tentang produksi kina telah dilakukan di tahun 2018 dan 2019. Hasilnya menunjukkan hanya pabrik kina Bukit Unggul ${ }^{2}$. Jejak kebun dan pabrik kina lainnya berupa bekas lokasi, sisa pondasi, dan struktur bangunan, serta bekas lahan kebun kina yang telah menjadi kebun teh, sayuran, kopi, dan lahan kosong yang terabaikan (Nuralia, 2018). Mengapa hanya tinggal satu pabrik yang masih beroperasi, dan mengapa kehilangan bangunan pabrik menjadi penting di masa sekarang, menjadi permasalahan pokok dalam tulisan ini.

Metode penelitian yang digunakan adalah Metode Penelitian Arkeologi terdiri dari empat tahapan, yaitu pengumpulan dan klasifikasi temuan, pemilahan dan verifikasi data, data atau evidence diberi konteks dan dianalisis, dan interpretasi (Dark, 1995).

\footnotetext{
${ }^{1}$ Berdasarkan Undang-Undang Agraris 1870 lahan yang tersedia untuk disewa oleh perusahaan perkebunan adalah woeste gronden, tanah "liar", artinya tidak digarap oleh penduduk bagi usaha taninya. Letak perkebunan pada umumnya jauh dari pedesaan, namun masih dapat dijangkau oleh tenaga kerja yang berasal dari pedesaan (Kartodirdjo dan Djoko Surjo, 1991: 143).

${ }_{2}^{2}$ Pabrik kina Bukit Unggul sekarang terletak di Afdeling Bukit Unggul-Sukawana, Perkebunan Ciater, PTPN VIII (Informasi diperleh dari Ervi Permana, Bagian Umum Perkebunan Ciater. Februari 2021).
} 
Pendekatan yang digunakan adalah pendekatan sejarah dengan menggunakan arsip kolonial (peta dan foto lama). Penelitian perkebunan masa kolonial termasuk penelitian arkeologi industri dengan teknik pengumpulan mengacu kepada framework arkeologi industri, yaitu surface surveys, excavations, archival research, oral history interviews (Casella, 2005). Akan tetapi, ekskavasi tidak dilakukan karena belum diperlukan.

\section{PEMBAHASAN}

Tanaman kina yang dikenal sekarang ada dua species, yaitu Cinchona Succirubra (batang atas) dan Cinchona Ledgeriana (batang bawah). Budidaya kina dilakukan dengan cara stek sambung. Penanaman pohon kina yang telah mengalami masa pembibitan dilakukan di awal musim hujan, sedangkan pemanenan di awal musim kemarau. Manfaat kina adalah kandungan yang ada di dalam kulitnya, yaitu senyawa alkaloid kina (quinine) sebagai obat anti malaria atau antipiretik, yang juga berefek menyegarkan tubuh. Senyawa alkaloid kina lainnya adalah quinide, yaitu senyawa anti arythmic, ophthalmia, internal haemorrhoid, dan hiccups (van Hall, 1946), untuk mengobati penyakit jantung.

Tanaman kina pertama kali ditanam di Kampung Genteng, Desa Jayagiri, Kecamatan Lembang, Kabupaten Bandung Barat. Orang yang berjasa membawa kina ke Indonesia adalah Dr. Friedrich Franz Wilhem Junghuhn (1809-1864), seorang Jerman yang berprofesi sebagai dokter, ahli tanaman (botanis), ilmuwan. Diceritakan pada tahun 1835 Junghuhn tiba di Batavia, Hindia Belanda. Sebelumnya transit di India dan membawa bibit kina ilegal. Kemudian di tahun 1848, Junghuhn kembali ke Eropa dan di tahun 1855 kembali ke Hindia Belanda. Pada tahun 1854, tanaman kina dibawa oleh

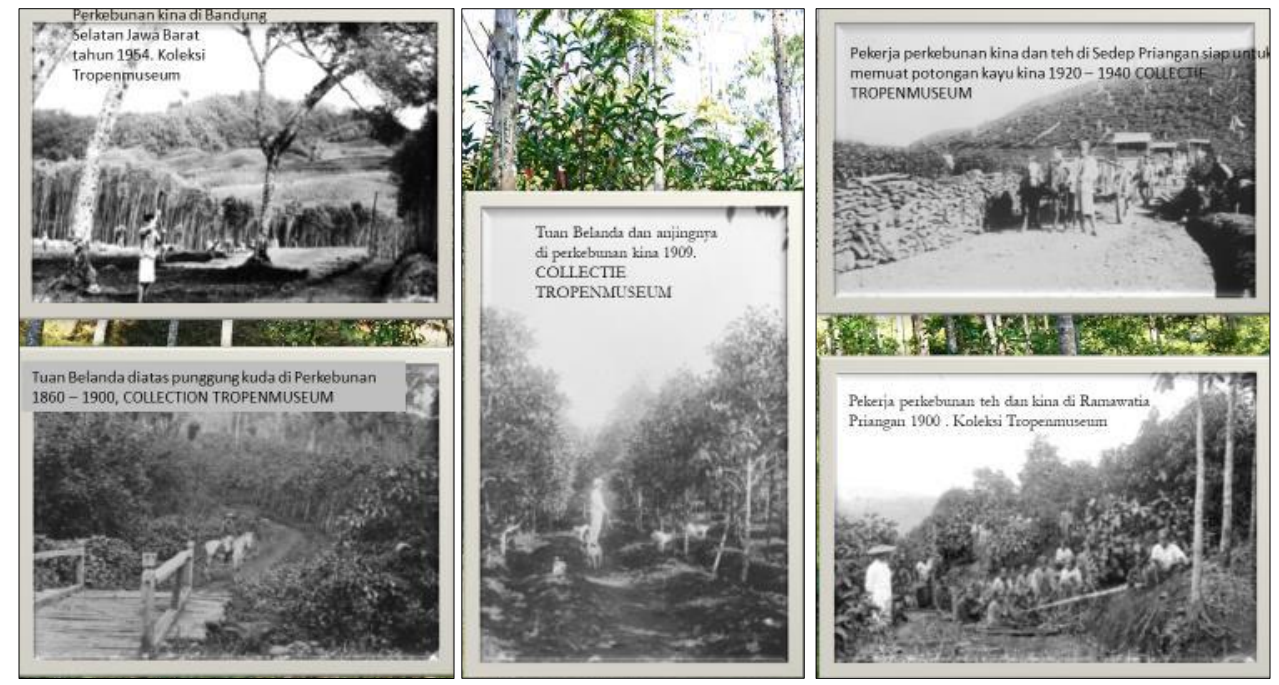

Gambar 1: Foto Lama Kebun Kina di Wilayah Bandung Selatan (Kebun Cinyiruan dan Kebun Kertamanah), Priangan Jawa Barat (Sumber: Laporan Pebenelitian Balai Arkeologi Jawa Barat. 2018). 
Haeskarl ke Hindia Belanda dari Amerika Selatan. Haskarl adalah utusan resmi Pemerintah Hindia Belanda, sehingga Haskarl menjadi salah seorang pembawa kina yang juga berjasa (Schrijver, 1928).

Perkebunan kina pertama kali dibuka adalah Kebun Cinyiruan dan Kebun Kertamanah (Reitsman, 1990), seperti tampak di foto lama (Tropen Museum Collectie, n.d.) (Gambar 1). Kebun Kina Cinyiruan didirikan oleh Pemerintah Belanda 17 Desember 1855, sedangkan Kebun Kina Kertamanah pertama kali didirikan oleh G.C Brunting sekitar tahun 1870-an. Perkebunan Kina Cinyiruan atau Gouvernement Kina Onderneming Tjinjiroean (Peta Topografi Blad 32 B/Alg. No. XL 38-B, 1919 - 1923. (n.d.)., n.d.), berdiri di Pangalengan dibawah pengawasan Junghuhn. Pada tahun 1856, Junghuhn menggalakkan penanaman kina dan pendirian perkebunan baru. Jauh sebelumnya Junghuhn juga telah melakukan penyesuaian iklim, percobaan tanaman kina di Cibodas Lembang. Selanjutnya di tahun 1865, seorang Inggris bernama Ledger, membawa species kina baru. Namanya diabadikan sebagai Cinchona Ledgeriana, species kina bagian batang bawah digunakan dalam budidaya tanaman kina dengan cara stek sambung. Pohon kina atau kulit kayu Peru, yang dihasilkan untuk pembuatan pil kina, dibawah pengaturan pemerintah, mulai bergerak secara perlahan di akhir tahun 1850-an (Schrijver, 1928).

Tanaman kina ditanam di dataran tinggi Priangan Jawa Barat. Menjelang tahun 1930-an ada sekitar 16.000 hektar kebun kina dan menghasilkan sekitar 12.000 ton dalam satu tahun. Pada zaman malaise kemudian mengalami penurunan produksi, tetapi dalam jumlah sedikit sekali (O' Malley, 1988). Kemudian tahun 1940 merupakan tahun puncak kejayaan produksi kina dari Hindia Belanda. Hampir 90\% kebutuhan bubuk kina dunia dipasok dari Jawa Barat, sebagian besar dari Bandung, sehingga Bandung terkenal sebagai ibukota kina ketika itu. Sementara itu, pada masa sekarang Indonesia masih menghasilkan produksi kina, tetapi jumlahnya menurun drastis.

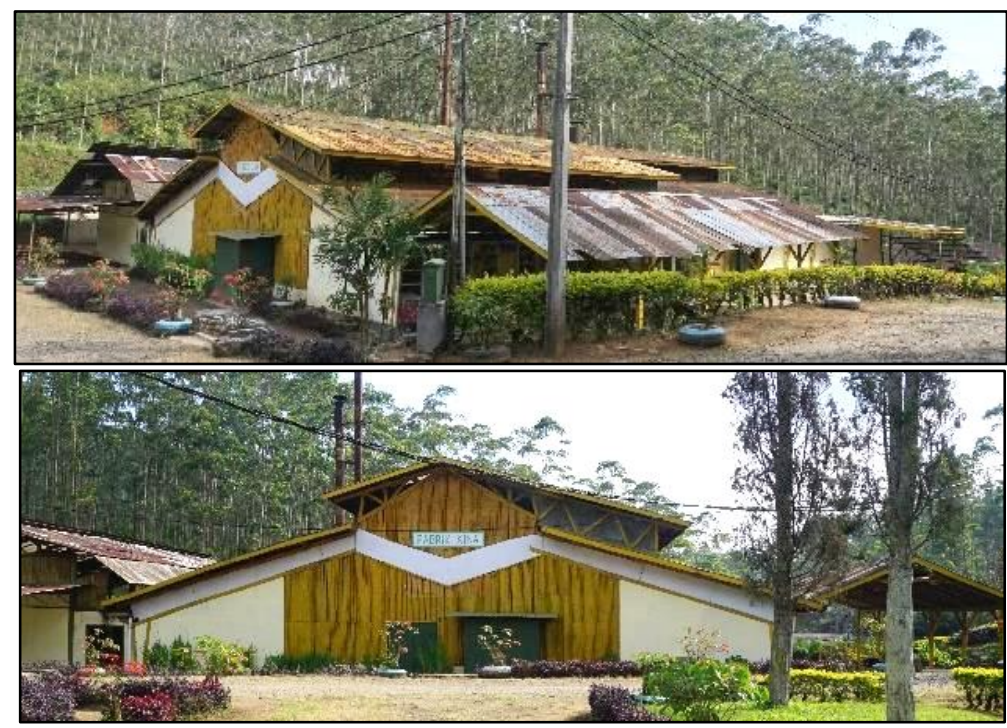

Gambar 2: Pabrik Kina Bukit Unggul Perkebunan Bukit Unggul-Sukawana (Sumber: Dokumen Balai Arkeologi Jawa Barat, 2018). 
Pada tahun 2009 Perkebunan Bukit Unggul-Sukawana dengan produksi teh dan kina, membawahi areal konsesi seluas 5.242,4 hektar, gabungan dari 15 kebun kina di enam kabupaten di Jawa Barat, yaitu: Garut, Bandung, Bandung Barat, Cianjur, Subang, dan Bogor. Hal ini berdasarkan SK Direksi No.SK/D.I/254/IV/2009. Nama kebunkebun tersebut, yaitu Pangheotan, Goalpara, Gunung Mas, Kertamanah, Malabar, Purbasari, Pasirmalang, Rancabolang, Sinumbra, Rancabali, Talun-Santosa, Tambaksari, Ciater, Dayeuhmanggung, Pondok Gedeh. Kantor Induk Administrasi Perkebunan Bukittunggul-Sukawana di Desa Cipanjalu, Kecamatan Cilengkarang, Kabupaten Bandung. Sementara itu, kebun dan pabrik kina Bukit Unggul berdiri sejak 1912 (Gambar 2).

Bibit kina waktu itu diperoleh dari Kebun Kertamanah, Pangalengan (Wardini et al., 2010). Berdasarkan laporan tahun 2015-2020, luas kebun kina menghasilkan mengalami penyusutan. Pada tahun 2015 luas kebun kina 468,76 ha; tahun 2016 luas 498,94 ha; tahun 2017 luas 498,94 ha; tahun 2018 luas 478,83 ha; tahun 2019 luas 478,82 ha; dan tahun 2020 luas kebun menjadi 384,49 ha. $^{3}$

Manfaat kina sebagai obat semakin meningkat namun perkebunan kina milik negara semakin menurun mulai tahun 2009-2014. Produksi kina sekitar 500 ton per tahun. Kebun Bukit Unggul masih memiliki kebun kina. Selain sebagai sumber pengadaan bahan kulit kina basah (K2B), juga sebagai upaya pelestarian tanaman kina sebagai tanaman "legendaris" yang pernah jaya di masa lalu. Pabrik Kina Bukit Unggul yang sekarang ada adalah bekas Pabrik Kina Cisarua (Og. Tjisaroewa, 21 Maret 1881), sehingga merupakan heritage industri perkebunan. Pabrik Kina Bukit Unggul ini adalah industri hulu yang menghasilkan produksi barang setengah jadi, yaitu bubuk kina atau kulit kina kering tepung (K3T). Selanjutnya K3T akan dikirim ke industri hilir untuk diolah kembali menjadi barang siap konsumsi, yaitu ke PT SIL (Sinkona Indonesia Lestari), masih anak cabang perusahaan PTPN VIII. ${ }^{4}$

Tabel 1: Kebun/Pabrik Kina yang Tergabung dalam Perkebunan Kina Bukit Unggul

\begin{tabular}{cll}
\hline No. & Nama Pabrik/Kebun & Pendirian Kebun/Pabrik \\
\hline 1. & Sukamanah (I, II, III) & 1876; 13 Agustus 1881; 29 April 1887 \\
\hline 2. & Cisarua & 21 Maret 1881 \\
\hline 3. & Gegersunten/Cikapundung (I, II) & 22 Agustus 1881 dan 4 Juni 1884 \\
\hline 4. & Panglipur Galih & 3 Februari 1833 \\
\hline 5. & Gunung Kasur & 1 Agustus 1884 \\
\hline 6. & Pangparang/Gunung Pangparang & 27 Mei Agustus 1884 \\
\hline \multicolumn{2}{l}{ Sumber: Regeerings Almanak 1880, 1892, 1893, 1898, 1902, 1906; dan Laporan Hasil Penelitian Tahun 2019. }
\end{tabular}

Tabel 2: Bekas Kebun/Pabrik Kina di Wilayah Bandung Jawa Barat

\begin{tabular}{cll}
\hline No. & Nama Pabrik/Kebun Kina & Pendirian Kebun/Pabrik Kina \\
\hline 1. & Cinyiruan & 17 Desember 1855 \\
\hline 2. & Sukawana (I, II, II, IV) & 4 Agus 1877; 6 Jan 1879; 24 Fe 1881; 24 Feb 1881 \\
\hline
\end{tabular}

\footnotetext{
3 Wawancara dengan Administratur/Dedi Lutfi Trisnadi dan Bagian Umum/Ervi Permana, Perkebunan Bukit Unggul-Sukawana, 2018 dan 2019.

${ }^{4}$ Wawancara dengan Administratur (Dedi Lutfi Trisnadi) dan Bagian Umum (Ervi Permana), Perkebunan Bukit Unggul-Sukawana, 2018 dan 2019.
} 


\begin{tabular}{lll}
\hline 3. & Cibitu & 1880-an \\
\hline 4. & Kertamanah (I, II, III, IV) & 30 Mei 1877; 16 Jan 1884; 12 Feb 1892; 13 Jan 1908; 29 Nov 1911 \\
\hline 5. & Pasir Malang (I, II, II) & 16 Juni 1880 ; 31 Maret 1883;18 Nov 1904 \\
\hline 6. & Riung Gunung & 1880-an \\
\hline 7. & Cikembang (I, II, III, IV, V) & 20 Juni 1882; 9 Sept 1885: 10 Juli 1890; April 1896; 23 Agus 1900 \\
\hline 8. & Lodaya & 26 Sept 1884; 5 Jan 1885; 20 April 1900 \\
\hline 9. & Rancabali (I, R, II) & 10 Maret 1885; 26 April 1898; 18 Nov 1901 \\
\hline 10. & Negla & 22 September 1887 \\
\hline 11. & Sukamanah Passer & 29 April 1887 \\
\hline 12. & Friesland/Pangheotan 2 (I, II) & 4 Maret 1890; 23 Nov 1894); \\
\hline 13. & Wanasuka (I, II) & 17 November 1892; 3 Okt1911 \\
\hline 14. & Malabar & 9 Januari 1893 \\
\hline 15. & Santosa (I, II, III, IV-VII) & 19 Juni 1894; 19 Juni 1894; 9 April 1896;(IV-VII) 27 Maret 1908 \\
\hline 16. & Sedep & (I -IV) 16 Mei 1896 \\
\hline 17. & Rancabolang (I, II) & 10 Desember 1905; 6 Desember 1906 \\
\hline 18. & Sperata (I, II, III, IV, V) & 21 Feb 1907; 8 April 1907; 27 Jan 1908; 25 Mar 1909; 25 Mar 1909 \\
\hline 19. & Talun (I, II, III, IV) & (I-IV) 4 Juli 1907 \\
\hline 20. & Sinumbra & 14 Oktober 1910 \\
\hline Sumber: Regeerings Almanak 1880, 1892, 1893, 1898, 1902, 1906 ; dan Laporan Hasil Penelitian Tahun 2019.
\end{tabular}

Tabel 1 menunjukkan enam pabrik kina di masa lalu (Widjaya, 2009) (Gambar 3) yang sekarang tinggal satu pabrik, yaitu Pabrik Kina Bukit Unggul sebagai bekas Pabrik Kina Cisarua. Jejak kelima pabrik lainnya berupa sisa pondasi batu (Pabrik Kina Panglipur Galih), tanah kosong dengan rumput ilalang (Pabrik Sukamanah), lahan tanaman sayuran (Pabrik Kina Gegersunten), lahan kosong (Pabrik Kina Gunung Kasur), serta sisa pondasi batu, pohon ekaliptus, dan rumput ilalang (Pabrik Kina Pangparang).

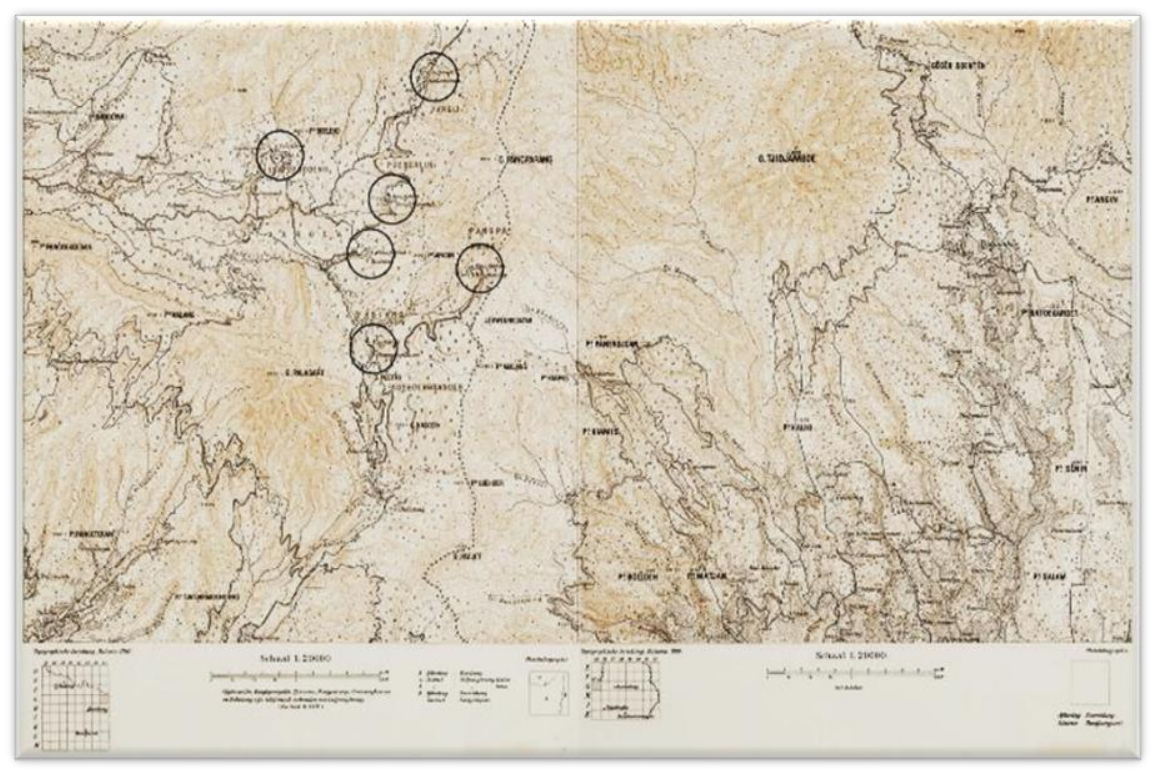

Gambar 3: Peta wilayah Gegersunten, Panglipurgalih, Tjisarua, Pangparang, Gunungkasur, dan Palintang 1904 oleh Topographisch Inrichting-Batavia 1910 (Widjaya, 2009)

Tabel 2 menguraikan 20 bekas pabrik kina yang masih dapat ditelusuri jejaknya, baik melalui observasi langsung ke lokasi maupun informasi kesejarahan melalui arsip kolonial. Jejak Pabrik Kina Cinyiruan, Cibitu, Riung Gunung, Lodaya, dan Sinumbra III 
(Sperata), yang ditemukan berupa sisa pondasi batu. Kemudian Pabrik Kina Kertamanah berupa struktur kerangka besi dan Pabrik Kina Cikembang berupa struktur batu. Selanjutnya jejak pabrik kina lainnya berupa lahan kosong, sisa kebun kina, alih fungsi menjadi kebun teh, kopi, dan sayuran, serta padang rumput ilalang.



Gambar 4: Bekas Pabrik Kina Cinyiruan Perkebunan Kertamanah (Sumber: Dokumen Balai Arkeologi Jawa Barat, 2019).



Gambar 5: Foto Lama Emplasemen Kebun Cinyiruan (Sumber: Koleksi Karyawan Kebun di Komplek Jejer 10 Cinyiruan. Scan Foto Nuralia Lia, 2019).

Jejak pabrik kina Cinyiruan Perkebunan Kertamanah berupa sisa pondasi batu, yang di atas lahannya telah didirikan bangunan baru (Gambar 4). Bangunan yang tampak sekarang adalah rumah karyawan, posyandu Aster 21, dan bangunan lainnya. 
Informasi tentang emplasemen permukiman Kebun Kina Cinyiruan di masa lalu dapat diketahui dari foto lama denah emplasemen. Tampak dalam foto lama tersebut ada empat bangunan pabrik kina berdekatan (atap jolopong atau rumah kampung), terdiri dari bangunan penjemuran, penggarangan, penggilingan, dan pengepakan (Gambar 5).

Produksi industri perkebunan memiliki rangkaian proses produksi, yaitu pengadaan bahan mentah di kebun dan pengolahan bahan mentah di pabrik. Pengadaan bahan mentah mulai dari pembibitan, penanaman, pemanenan, dan pengangkutan ke pabrik. Kemudian pengolahan di pabrik berawal dari penerimaan bahan mentah dari kebun, berupa kulit kina basah (K2B). K2B kemudian dikeringkan dengan cara dijemur dan digarang. Penjemuran merupakan pengeringan alami oleh sinar matahari secara tidak langusung, yaitu ditebar di lantai bangunan yang beratap tetapi tidak berdinding, sampai menjadi kulit kina kering jemur (K3J). Penggarangan dilakukan dengan menggunakan mesin penggarangan dan tungku api (Sirroco), sehingga menjadi kulit kina kering garang (K3G). Proses terakhir adalah penggilingan K3G oleh mesin penggilingan sampai menjadi kulit kina kering tepung (K3T) (Nuralia, 2018).

Produksi kina mengalami penuruan drastis atau dapat dikatakan mengalami kehancuran. Pada tahun 2018 kebun kina Bukit Unggul terdiri dari 51 blok kebun, luas tanaman kina menghasilkan (TM) 566, 76 ha dan 116, 49 ha tanaman belum menghasilkan (TBM), serta 10.10 ha tanaman entrys dan pesemaian, 31,19 ha emplasemen (Selayang Pandang Perkebunan Bukit Unggul-Sukawana Tahun 2018, 2018). Kemudian di tahun 2019 dan 2020 produksi sedikit mengalami penurunan, karena terimbas faktor perubahan manajerial kebun dan kepemimpinan. Akan tetapi di tahun 2021 meningkat kembali sedikit, dengan areal tanaman kina yang menghasilkan di sekitar 776 ha, dengan rata-rata produksi per tahun sekitar 30 ton $^{5}$.

Areal kebun kina Bukit Unggul dari tahun 2019 sampai 2021 ini sudah tidak memiliki kebun pesemaian lagi. Produksi yang meningkat menjadi pertanda baik, tetapi dengan tidak adanya kebun pesamaian lambat laun tanaman kina berkurang dan berimbas kepada berkurangnya bahan baku kulit kina basah. Penuruan jumlah kulit kina tersebut akan mengurangi hasil olahan kulit kina di pabrik. Juga tidak ada lagi bahan baku kulit kina dari kebun lain. Kehancuran produksi secara otomatis mengakibatkan pabrik kina beroperasi minimalis sampai akhirnya dikhawatirkan akan berhenti beroperasi, mesin tidak difungsikan, bangunan terabaikan, dan akhirnya jejak kebun dan pabrik akan hancur atau hilang perlahan dimakan zaman.

Proses produksi kina di masa lalu sudah menjadi tradisi produksi di masa sekarang. Demikian juga dengan kehidupan sosial komunitas perkebunan di masa lalu, masih ada kesamaan dengan kehidupan sosial masyarakat perkebunan di masa sekarang. Tradisi produksi dan kehidupan sosial komunitas perkebunan menjadi warisan budaya tak benda. Apabila produksi kina menurun dan akhirnya punah, otomatis kehidupan sosial komunitas perkebunan kina pun akan hilang dan tinggal cerita lama tanpa jejak atau bukti.

\footnotetext{
${ }^{5}$ Informasi terbaru diperoleh dari Bagian Umum Kebun Bukit Unggul Perkebunan Ciater (Ervi Permana, 22 Februari 2021).
} 
Bangunan pabrik kina adalah bangunan produksi utama. Sekarang hanya satusatunya pabrik kina yang masih beroperasi. Bangunan pabrik kina lainnya telah hancur karena tidak difungsikan dan terabaikan. Keadaan tersebut bisa disebut sebagai satu bencana budaya, karena kehancuran produksi mengakibatkan hilangnya pabrik kina.

Mengapa bangunan pabrik kina tersebut penting dan menjadi satu bencana budaya ketika hancur dan hilang, karena beberapa alasan fisik dan nonfisik. Alasan fisik dilihat dari perspektif wujud, luas lahan, ukuran, dan fungsi bangunan. Wujud atau tampilan bangunan dengan bahan dan teknologi yang digunakan. Menurut pendapat Nobel Elias (Elias, 1983) dikatakan bahwa struktur tempat tinggal atau bangunan menjadi indikator struktur sosial. Bangunan besar dan megah berdiri di atas lahan luas dengan fungsi penting, menjadi petunjuk besarnya fungsi bangunan tersebut. Fungsi bangunan pabrik kina di masa lalu sangat besar. Pabrik Kina Bukit Unggul memiliki luas bangunan sekitar 800 meter $^{2}$, bangunan satu atap yang terbagi menjadi empat ruangan.

Wujud fisik mencerminkan bahasa nonverbal yang mengandung makna tertentu, sebagai kode budaya kolonial. Kode budaya tersebut tercermin dari bentuk dan gaya arsitektur, tata letak dalam ruang emplasemen, serta jarak antar bangunan dan asosiasinya dengan bangunan lain. Keadaan nonfisik bisa diketahui sebagai bentuk komunikasi nonverbal, yang bercerita tentang berbagai hal berhubungan dengan produksi dan kehidupan sosial masyarakat perkebunan (Nuralia, 2016).

Produksi kina di kebun dan pabrik di masa lalu, prosesnya masih bisa dilihat di masa sekarang. Proses produksi tersebut masih mengadopsi proses produksi yang telah lampau. Kesinambungan cara produksi menjadi satu kebiasaan sampai sekarang sehingga menjadi tradisi produksi. Demikian juga dengan kehidupan sosial masyarakat perkebunan sekarang menjadi cerminan dari kehidupan sosial masyarakat perkebunn di masa lalu. Kehancuran produksi mengakibatkan kehilangan bangunan produksi, sekaligus secara langsung atau tidak langsung akan kehilangan tradisi produksi dan informasi tentang kehidupan sosial masyarakat perkebunan masa lalu. Keadaan tersebut menjadi satu petaka dalam kehidupan masyarakat perkebunan khususnya.

Petaka dalam kehidupan masyarakat perkebunan akan menjadi bencana budaya, apabila tidak segera ditanggulangi. Tidak hanya bencana budaya, juga menjadi bencana sosial, yaitu hilangnya pekerjaan bagi para pengelola (pejabat/unsur pimpinan) dan karyawan perkebunan. Kenyataan di masa sekarang, kehancuran produksi mengakibatkan banyak tenaga kerja yang diberhentikan. Pabrik hanya mengolah kina satu bulan sekali, karena kulit kina basah yang dihasilkan sudah menurun, pohon kina semakin menyusut jumlahnya. Pembibitan atau pesemaian tanaman kina sudah tidak dilakukan ${ }^{6}$.

Faktor lain dari kehancuran produksi dan hilangnya bangunan pabrik kina diduga, terkait juga dengan masalah fungsi kandungan dalam pohon kina. Salah satunya adalah fungsi quinine. Fungsi quinine sekarang telah digantikan dengan obat anti

\footnotetext{
${ }^{6}$ Wawancara dengan Administratur/Manajer, dengan Bagian Umum, dengan Kepala Pengolahan, serta karyawan kebun dan pabrik di Bukit Unggul (2018 dan 2019).
} 
malaria sintetik, yaitu chloroquine. Penggantian tersebut terjadi ketika muncul penyebab malaria yang resisten terhadap obat anti malaria sebelumnya. Senyawa alkaloid kina (quinine) sekarang lebih banyak dimanfaatkan sebagai penambah rasa pahit pada minuman, kandungan shampoo, minyak rambut, insektisida, vulcanizing pada produksi karet, serta preparasi beberapa jenis logam. Akan tetapi, fungsi zat quinine dan quinidine alami akan kembali menjadi perhatian, karena diduga mampu memberi solusi untuk mengatasi pandemi sekarang ini. Dengan demikian, harapan akan kembali ada untuk mengatasi kehancuran produksi kina, sehingga bencana budaya dan bencana sosial tersebut tidak akan terjadi secara permanen.

\section{SIMPULAN}

Pabrik kina di Bandung Jawa Barat khususnya yang memproduksi kulit kina kering tepung (K3T) tinggal satu pabrik, yaitu Pabrik Kina Bukit Unggul. Kelangsungan produksi kina di industri hulu ini mengalami penurunan drastis karena ketersediaan bahan baku kulit kina basah tinggal sedikit, hanya bisa dipenuhi oleh kebun sendiri secara lokal.

Kehancuran produksi di industri hulu akan berimbas kepada penurunan produksi di industri hilir. Perlahan jejak kina pun akan hilang dan keadaan ini menjadi satu petaka sosial bagi masyarakat perkebunan, karena kehilangan mata pencaharian. Sementara itu, berhentinya produksi mengakibatkan berhentinya fungsi bangunan pabrik, sampai akhirnya terabaikan dan hilang. Bangunan pabrik lama adalah warisan budaya benda, sehingga kehancurannya menjadi petaka budaya.

Warisan budaya perkebunan berupa bangunan pabrik kina menjadi penting karena bernilai sejarah dan sumber ilmu pengetahuan. Kemudian pengetahuan tentang tradisi produksi dan kehidupan sosial masyarakat perkebunan, mengakibatkan terputusnya mata rantai pengetahuan lokal yang sangat bermanfaat. Keadaan tersebut menjadi bencana budaya dan bencana sosial dalam sejarah kebudayaan Indonesia.

\section{UCAPAN TERIMA KASIH}

Ucapan terimakasih saya tujukan kepada direksi PTPN VIII, manajer Perkebunan Bukit Unggul-Sukawana, Kertamanah, Rancabali, Pasirmalang, Talun Santosa, Sinumbra, Purbasari, Sedep, dan Malabar. Terima kasih kepada teman-teman satu tim tahun 2018 dan 2019, yang telah banyak membantu dalam pencarian data di lapangan. Selanjutnya terimakasih kepada Bapak Ervi Permana, bagian umum Perkebunan Perkebunan Ciater, yang telah memberi informasi terkait produksi kebun Bukit Unggul.

\section{DAFTAR PUSTAKA}

Breman, J. (2014). Keuntungan Kolonial dari Kerja Paksa: Sistem Priangan dari Tanam Paksa Kopi di Jawa 1720-1870. Yayasan Pustaka Obor Indonesia.

Casella, E. C. (2005). Industrial Archaeology: Future Directions (E. C. C. and J. Symonds. (Ed.)). 
Dark, K. R. (1995). Theoretical archaeology. Ithaca and New York: Cornell University Press.

Elias, N. (1983). The Court Society (T. E. Jephcott. (Ed.)). Basil Blackwell Publisher Limited.

Hermans, W. F. (1988). Multatuli yang penuh teka-teki (S. T. KITLV-LIPI (Ed.). Djambatan.

Kartodirdjo, S., \& Surjo, D. (1991). Sejarah perkebunan di Indonesia: kajian sosialekonomi. Aditya Media.

Kurniawan, H. (2014). Dampak Sistem Tanam Paksa terhadap Dinamika Perekonomian Petani Jawa 1830-1870. SOCIA: Jurnal Ilmu-Ilmu Sosial, 11(2), 163-172.

Nuralia, Lia, dkk. (2019). Bangunan Industri dan Produksi Perkebunan Kina Kabupaten Bandung Barat dan Sekitarnya, Provinsi Jawa Barat, Abad XIX - XX Masehi.

Nuralia, L. (2015). Peran Elite Pribumi dalam Eksploitasi Kapitalisme Kolonial: Komparasi Antara Prasasti dan Arsip. Purbawidya Jurnal Penelitian dan Pengembangan Arkeologi, 4(1), 39-54.

Nuralia, L. (2016). Situs Perkebunan Cisaga 1908-1972: Kajian Arkeologi Industri tentang Kode Budaya Kolonial. Universitas Indonesia.

Nuralia, L. (2018). Bangunan dan Produksi Perkebunan Panglejar dan Bukit UnggulSukawana Kabupaten Bandung Barat, Provinsi Jawa Barat.

O, M. (1988). Perkebunan 1830-1940: Ikhtisar. In A. W. Anne Booth, William J. O’Malley (Ed.). In Sejarah Ekonomi Indonesia (hal. 136). LP3ES.

Peta Topografi Blad 32 B/Alg. No. XL 38-B, 1919 - 1923. (n.d.). (n.d.). Universiy Libraries.

Regerings Almanak voor Nederlandsch-Indie (1892, 1893,1900, 1901, 1902, 1906) Eeerste Gedeelte, Grondgebied en Bevolking, Inrrichting Van Het Bestuur Van Nederlandsch-Indie En Bijlagen. (1892).

Reitsman, S. A. (1990). Bandoeng The Mountain City of Netherlands India.

Schrijver, V. (1928). De Kina van Boschprodukt tot Kultuutgewas (Openbare Les Gehouden Op 27 September 1928 Bij Den Aanvang van Zijn College over De Kultures van den Ned. Indischen Archipel Door DR. Z. Kamerling, Privaat-Docent Aan DE Rijks-Universiteit Te Leiden. N.V. Boek-E.

Selayang Pandang Perkebunan Bukit Unggul-Sukawana Tahun 2018. (2018).

Simarmata, R. (2002). Kapitalisme perkebunan dan konsep pemilikan tanah oleh negara. Insist Press.

Sutherland, H. (1983). Terbentuknya Sebuah Elite Birokrasi. Tropen Museum Collectie. Sinar Harapan.

van Hall, C. J. . en C. V. D. K. (1946). De Lanbouw In Den Indischen Archipel, In drie deelen. Deel I Algemeen Gedeelte. Uitgevereij W. Van Hoeve 's-Gravenhage. MCMXLVI.

Van Niel, R. (1988). Munculnya Elit Modern Indonesia. Pustaka Jaya.

Wardini, C., Permadi, G., Muhammad Iqbal, \& Widianti, N. (2010). Dari Bumi Pasundan Menembus Dunia, Perjalanan Panjang PT Perkebunan Nusantara VIII. PT Perkebunan Nusantara VIII.

Widjaya, A. S. (2009). Ujung Berung Serambi Timur Bandung. Panitia Pameran Sejarah Ujungberung. 


\section{HASIL DISKUSI}

\section{Pertanyaan}

1. Adnan (Alqa Print Jatinangor)

Produksi perkebunan kina mengalami penurunan drastis. Kenapa terjadi penurunan luas area? Apakah nilai ekonomis berkurang?

\section{Jawaban}

1. Ketika kebun diambil alih awal kemerdekaan, ada satu gejolak besar-besaran seperti SDM, selain itu ada pengganti kulit kina menjadi sintetis. 